\title{
Small-intestinal and Gastric Changes in Ulcerative Colitis : a Biopsy Study
}

\author{
S. N. SALEM,* M.B., CH.B., M.R.C.P.ED. ; S. C. TRUELOVE,* M.D., F.R.C.P. ; W. C. D. RICHARDS, † M.B., B.S.
}

[With Special Plate]

Brit. med. F., 1964, 1, 394-398

When a patient suffers from a sharp attack of ulcerative colitis symptoms suggesting some disturbance of the upper gastrointestinal tract are common. Loss of appetite is usual and vomiting is not rare; these symptoms subside as the severity of the colitis declines.

We decided to make an objective study of the state of the stomach and small intestine in this disease, with special reference to the histological picture as judged by peroral biopsy specimens. In addition to obtaining gastric and small-intestinal specimens, it was our intention to make some studies of small-intestinal function. The full range of tests available for the study of this function takes a considerable time. In dealing with an attack of ulcerative colitis it is essential that treatment be given without undue delay, and, in addition, the patient is often not fit to withstand any disturbing investigation. It has therefore been necessary for us to restrict the tests to one or two which can be carried out in the course of a few days and which do not cause any upset. In the event it has proved possible to estimate the faecal fat excretion and the absorption of vitamin $B_{12}$ without inconveniencing the patient. Some patients were already on corticosteroid treatment at the time of our studies, but others with first attacks of the disease or with a recent relapse were studied before specific treatment was instituted.

The object of this paper is to present the results obtained in a pilot study along the lines just discussed and to consider future possibilities.

\section{Methods}

Small-intestinal Biopsy.-This was performed by means of the Crosby capsule (Crosby and Kugler, 1957). The site of the capsule was determined by fluoroscopy, by plain $x$-ray film, or, if the position was still doubtful, by an $x$-ray film taken after injection of $5 \mathrm{ml}$. of " urografin" through the tube leading to the capsule. The biopsy specimen was taken from the upper jejunum and was immediately placed in $10 \%$ formol-saline; it was then examined under the dissecting microscope, this being done within 15 minutes from the time of "firing" the Crosby capsule. The specimen was then embedded in paraffin wax and sections were taken at numerous levels in the block so that both vertical and tangential sections were available for histological study. These were stained with haematoxylin and eosin, and by the periodic-acid-Schiff method.

Gastric Biopsy.-This was usually also performed by means of the Crosby capsule, which is more comfortable for the patient than the Wood gastric biopsy tube which is commonly employed. The Crosby capsule yields a good-sized specimen for histological examination. Others have also found this capsule a convenient instrument for gastric biopsy (Floch and Sheehy, 1962). The gastric biopsy was usually performed about half an hour after the small-intestinal biopsy. The specimen was immediately fixed in $10 \%$ formol-saline for histological examination.

Faecal Fat.-Our usual practice has been to collect stools for four days while the patient was on a standard hospital diet, although sometimes eating much smaller quantities than customary. The method of van de Kamer et al. (1949) employing wet faeces was used to estimate total lipids. It has been established that healthy subjects on an ordinary diet excrete less than $5 \mathrm{~g}$. total fat daily, irrespective of considerable variations in the fat intake (Cooke, 1958). We have taken a faecal excretion of $6 \mathrm{~g}$. or more as abnormal.

Vitamin- $B_{12}$ Absorption.-This was measured by feeding a test dose of labelled vitamin $\mathrm{B}_{12}$ containing $0.5 \mu \mathrm{C}$ of ${ }^{58} \mathrm{Co}$. This was administered in about $50 \mathrm{ml}$. of water on an empty stomach. The stools were collected for five days thereafter and the amount of radioactivity in the faeces was measured against a standard made up from the same batch of radioactive vitamin $B_{12}$, using a phosphor-well scintillation counter. $B y$ this method normal subjects excrete less than $25 \%$ of the administered dose, whereas in pernicious anaemia, in which there is severely impaired absorption, the amount excreted is $75 \%$ $100 \%$ (Callender et al., 1954 ; Callender and Evans, 1955). The test of vitamin- $B_{12}$ absorption was usually carried out simultaneously with the study of faecal fat excretion in order to economize on time.

$X y l o s e$-excretion Test.-This has been demonstrated to be a fairly reliable test of small-intestinal absorption (Fourman, 1948 ; Benson et al., 1957). We employed it on the first three patients of the present study but found that the xylose caused abdominal discomfort and increased diarrhoea ; it was therefore abandoned. The modified test of Santini et al. (1961) employs a smaller dose of xylose and may be practicable to use in ulcerative colitis, but we have not yet tried it.

\section{Patients Studied}

Twenty-five patients were studied. They were all cases of classical ulcerative colitis. Some were in a frank attack of the disease at the time of study, but others were examined while in a stage of remission. Some patients were receiving corticosteroid treatment, but others were on no specific form of therapy.

In every case a barium enema was performed shortly before or shortly after the period of study. Sigmoidoscopy was carried out at about the same time, and in the great majority a biopsy specimen was taken from the lower sigmoid colon by means of a Truelove-Salt biopsy instrument.

Small-intestinal biopsy was carried out in all cases, but the full range of other types of investigation was not always feasible. The results are summarized in Table I.

\section{Small-intestinal Biopsy Findings}

The small-intestinal biopsy specimens were often abnormal as judged by the appearances under the dissecting microscope and histologically. Holmes et al. (1961a) showed that in idiopathic steatorrhoea the appearances under the dissecting microscope differ sharply from those observed with a normal small intestine. Since then it has been generally agreed that the dissecting-

* Nuffield Department of Clinical Medicine, University of Oxford. † Lecturer in the Department of Pathology, Radcliffe Infirmary. 
microscope appearances correlate well with histological changes. We have recognized the following categories (see Special Plate).

\section{Dissecting-Microscope Appearances}

Category I.-Most of the intestinal villi were slender, finger-like projections from the mucosal surface. In all but three specimens some leaf-shaped villi were present, but these were not numerous and their length rarely exceeded three times the maximum width of the finger-like villi.

Category II.-In addition to finger-like villi, numerous leafshaped forms were present. In every case some elongated leafshaped villi or villous ridges were found, and occasional branched and convoluted villi were visible. The summits of some leaf-shaped villi were partly divided by shallow indentations as if partial differentiation into smaller villous structures had occurred, and some leaf-shaped forms were bent into a U-shape in their transverse axis.

Category III.-Only a few finger-like villi were present. Many of the villi were leaf-shaped, but there were also areas in which elongated leaf-shaped villi and convoluted and folded villous ridges formed the bulk of the villous structures. The length of many of the villous ridges was between five and twelve times the width of finger-like villi; in some instances these villous ridges measured more than $2,000 \mu$ in length.

Category IV.-The mucosal surface was flat and completely devoid of villi.

\section{Histological Appearances}

No biopsy specimen in this series showed mucosal ulceration or neoplastic change. A single small crypt abscess was present in the mucosal biopsy specimen in Case 5, and typical subtotal villous atrophy of the jejunal mucosa was found in Case 3. With the exception of these two examples, inflammatory changes were absent, and the epithelium of the villi and glands was of normal appearance. In four biopsy specimens the presence of a small group of Brunner's gland acini either in the submucosa or in the deep part of the mucosa suggested that the biopsy specimen came from the neighbourhood of the duodenojejunal flexure.

Examination of histological sections cut at various levels in the biopsies, and study of sections cut in planes perpendicular and tangential to the mucosal surface, showed variations in the pattern of the villous zone which broadly corresponded with the variations in the villous pattern seen under the dissecting microscope. These histological variations could be summarized as follows :

Category 1.-The histological appearance in sections cut perpendicular to the mucosal surface was normal. Leaf-shaped villi were visible in tangential sections but no villous ridges or branched villi were seen. The majority of the villi measured less than $500 \mu$ in their maximum dimension, and no villous structures measuring more than $820 \mu$ in length were seen.

Category II.-Normal mucosal appearances or focal irregularities in villous shape were found on examination of sections cut in a plane perpendicular to the mucosal surface. Leaf-shaped villi were visible in tangential sections as in category $I$ but were more prominent. In all cases elongated villous ridges measuring more than $1,000 \mu$ in length were found in varying numbers. In some specimens these ridges were simple, unbranched structures, while in others the lower part of the villous zone consisted of a complex arrangement of branching and anastomosing villous ridges.

TABLE I.-Details of Patients Studied and the Results Obtained*

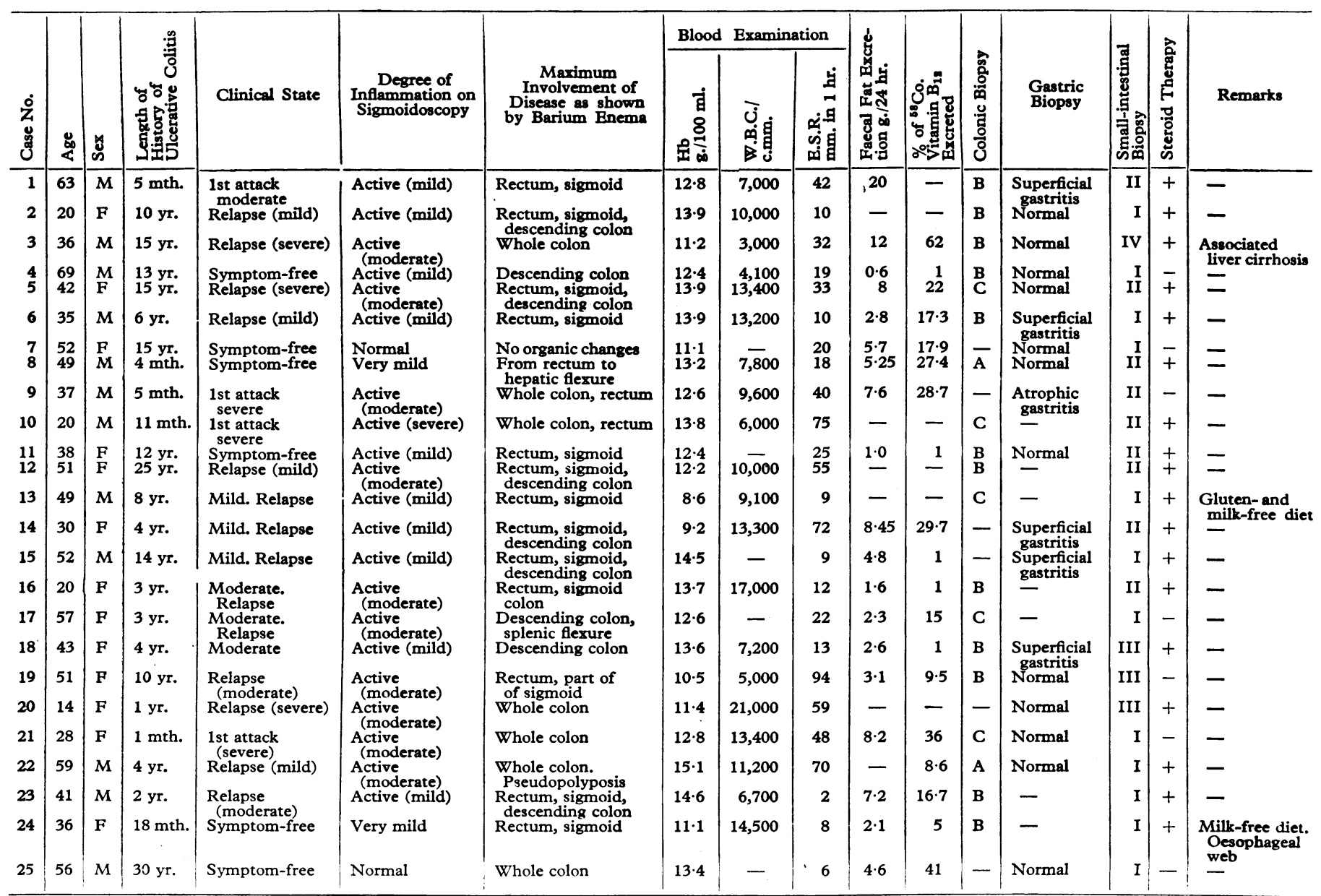

* The small-intestinal biopsy results are classified as I, II, III, and IV according to the descrintion in the text. The clinical severity of an attack of ulcerative colitis is shown as mild, moderate, or severe according to the grading employed by Truelove and Witts (1955). The colonic biopsy specimens have been graded according to the 
Category III.-In sections cut perpendicularly to the mucosal surface the histological appearance was variable. Some parts of the mucosa were normal except for slight increase in the thickness of the gland layer. In other areas broad, irregular villi, mucosal bridges, and bifid villi were visible. This variation in structure appeared to depend on whether the plane of section ran across or along the long axis of the leaf-shaped villi and ridges, the former resulting in a relatively normal picture, the latter showing irregularities due to oblique cutting of folded ridges and leaf-shaped structures. Tangential sections showed long anastomosing villous ridges which in the lower part of the mucosa enclosed clefts representing the intervillous space. Only occasional separate finger-like and leaf-shaped villi were present.

Category IV.-The mucosa showed typical subtotal villous atrophy with a flat mucosal surface and no projecting villous structures.

\section{Significance Attached to the Various Categories}

For the purpose of the present study we have regarded jejunal biopsy specimens falling in category I as normal, specimens falling in category II as showing minor abnormalities of villous structure, and specimens falling in category III as showing marked abnormalities of villous structure. (We appreciate that leaf-shaped villi and ridges have been found in small-intestinal biopsy specimens taken from normal subjects, but it is only in duodenal specimens that such appearances are common (Holmes et al., 1961b).)

\section{Relation of Small-intestinal Changes to Clinical State}

Table II shows that there is a definite correlation between the clinical state of the patient with ulcerative colitis and the findings on small-intestinal biopsy. Only two of the six patients studied while in clinical remission yielded abnormal small-intestinal biopsy specimens, and these showed only mild abnormalities. Similarly, only two of the seven patients with a mild attack of ulcerative colitis yielded abnormal small-intestinal biopsy specimens, and none of these was markedly abnormal. By contrast, 9 of the 12 patients studied in attacks of ulcerative colitis graded as moderate or severe yielded abnormal smallintestinal biopsy specimens, four of these showing marked abnormalities in villous structure.

TABLE II.-Relation Between Clinical Activity of Ulcerative Colitis and State of Small-intestinal Mucosa as fudged from Biopsy Specimen

\begin{tabular}{l|c|c|c|c}
\hline & \multicolumn{4}{|c}{ State of Small-intestinal Mucosa } \\
\cline { 2 - 5 } $\begin{array}{c}\text { Clinical State } \\
\text { as Regards } \\
\text { Ulcerative Colitis }\end{array}$ & \multicolumn{4}{|c}{ Category } \\
\cline { 2 - 5 } & I & II & III & IV \\
\hline $\begin{array}{l}\text { Symptom-free ... } \\
\text { Mild attack }\end{array}$ & 4 & 2 & & \\
Moderate or severe attack & 3 & 2 & 3 & 1 \\
\hline
\end{tabular}

It should be noted that the only patient showing subtotal villous atrophy resembling that seen in idiopathic steatorrhoea was a man with coexistent cirrhosis of the liver and ulcerative colitis. It is possible that the hepatic condition was more closely connected than the colitis with this small-intestinal picture, and it will be necessary to make additional studies to clarify the relationship.

\section{Length of History and Age of Patient}

The fact that the villous abnormalities are exceptional when the patient is symptom-free suggests that the small-intestinal abnormalities represent a transitory state. This is supported by the finding that the proportion of patients with abnormal small-intestinal biopsy specimens does not increase with increasing length of history of the ulcerative colitis. Indeed, the reverse is the case (Table III), and this may be linked with the fact that the first attack of ulcerative colitis is often severe.
TABLE III-Relation Between Length of History of Ulcerative Colitis and State of Small-intestinal Mucosa (Excluding Six Cases Studied when Symptom-free)

\begin{tabular}{|c|c|c|c|c|}
\hline \multirow{2}{*}{\multicolumn{3}{|c|}{$\begin{array}{l}\text { Length of History of } \\
\text { Ulcerative Colitis }\end{array}$}} & \multicolumn{2}{|c|}{ Small-intestinal Biopsy Specimen } \\
\hline & & & Normal & Abnormal \\
\hline $\begin{array}{l}<1 \text { year } \\
1-9 \text { years } \\
10+\text { years }\end{array}$ & $\begin{array}{l}\cdots \\
\therefore\end{array}$ & $\begin{array}{l}\ldots \\
\cdots\end{array}$ & $\begin{array}{l}1 \\
5 \\
2\end{array}$ & $\begin{array}{l}3 \\
4 \\
4\end{array}$ \\
\hline
\end{tabular}

The age of the patient has no bearing on the liability of the small-intestinal biopsy specimen to be abnormal, as is plain from Table IV.

TABLE IV.-Lack of Any Relation Between Age of Patient with Ulcerative Colitis and State of Small-intestinal Mucosa (Excluding Six Patients Who were Symptom-free)

\begin{tabular}{|c|c|c|c|c|c|c|}
\hline \multirow{2}{*}{\multicolumn{5}{|c|}{ Age of Patient }} & \multicolumn{2}{|c|}{ Small-intestinal Mucosa } \\
\hline & & & & & \multirow{2}{*}{$\begin{array}{c}\text { Normal } \\
2 \\
3 \\
3\end{array}$} & \multirow{2}{*}{$\begin{array}{c}\text { Abnormal } \\
3 \\
5 \\
3\end{array}$} \\
\hline $\begin{array}{l}<30 \\
30-49 \\
50+\end{array}$ & $\begin{array}{l}\ldots \\
\cdots\end{array}$ & $\begin{array}{l}\cdots \\
\cdots\end{array}$ & $\begin{array}{l}\cdots \\
\cdots\end{array}$ & $\begin{array}{l}\cdots \\
\cdots\end{array}$ & & \\
\hline
\end{tabular}

\section{Faecal Fat Excretion}

The faecal fat excretion was abnormally high in 7 of the 19 patients in whom this was studied. Abnormal values were found only in patients with clinically active ulcerative colitis (Table V). There was a close though not perfect association between the state of the small-intestinal mucosa as judged from the biopsy specimen and the faecal fat excretion (Table VI).

TABLE V.-Relation Between Clinical State and Faecal Fat Excretion

\begin{tabular}{|c|c|c|c|}
\hline \multicolumn{2}{|l|}{$\begin{array}{l}\text { Clinical State of } \\
\text { Ulcerative Colitis }\end{array}$} & No. of Patients & $\begin{array}{l}\text { No. with Abnormal } \\
\text { Faecal Fat Excretion }\end{array}$ \\
\hline $\begin{array}{l}\text { Symptom-free } \\
\text { Mild attack } \\
\text { Moderate or severe attack }\end{array}$ & $\begin{array}{l}\cdots \\
\therefore\end{array}$ & $\begin{array}{r}6 \\
3 \\
10\end{array}$ & $\begin{array}{l}0 \\
1 \\
6\end{array}$ \\
\hline Total & $\ldots$ & 19 & 7 \\
\hline
\end{tabular}

TABLE VI.-Relation Between State of Small-intestinal Mucosa, as fudged by Biopsy Specimen, and Faecal Fat Excretion

\begin{tabular}{|c|c|c|c|c|c|c|}
\hline \multirow{2}{*}{\multicolumn{5}{|c|}{ Small-intestinal Mucosa }} & \multicolumn{2}{|c|}{ Faecal Fat Excretion } \\
\hline & & & & & \multirow{2}{*}{$\begin{array}{c}\begin{array}{c}\text { No. of Patients } \\
\text { Examined }\end{array} \\
9 \\
10\end{array}$} & \multirow{2}{*}{ 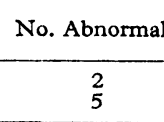 } \\
\hline $\begin{array}{l}\text { Normal } \\
\text { Abnormal }\end{array}$ & $\begin{array}{l}. \\
\cdots \\
\end{array}$ & $\begin{array}{l}\cdots \\
\cdots\end{array}$ & 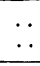 & $\because$. & & \\
\hline Total & . & . & . & . & 19 & 7 \\
\hline
\end{tabular}

\section{Corticosteroid Therapy}

This appears to have no bearing on the changes found on small-intestinal biopsy (Table VII).

TABLE VII.-Lack of Relation Between Corticosteroid Therapy and State of Small-intestinal Mucosa in Patients in an Attack of Ulcerative Colitis. (Six Patients Who were Symptom-free Have Been Excluded)

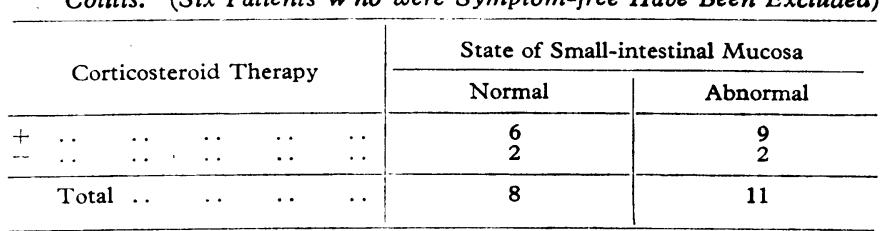

\section{Absorption of Vitamin $\mathbf{B}_{12}$}

This was measured in 19 patients and was severely abnormal in only one, who was the patient with cirrhosis of the liver 
Range of appearances shown by jejunal biopsy specimens in ulcerative colitis. The top row shows the appearances on examination with the dissecting microscope $(x 16)$. The second row shows the

CATEGORY I

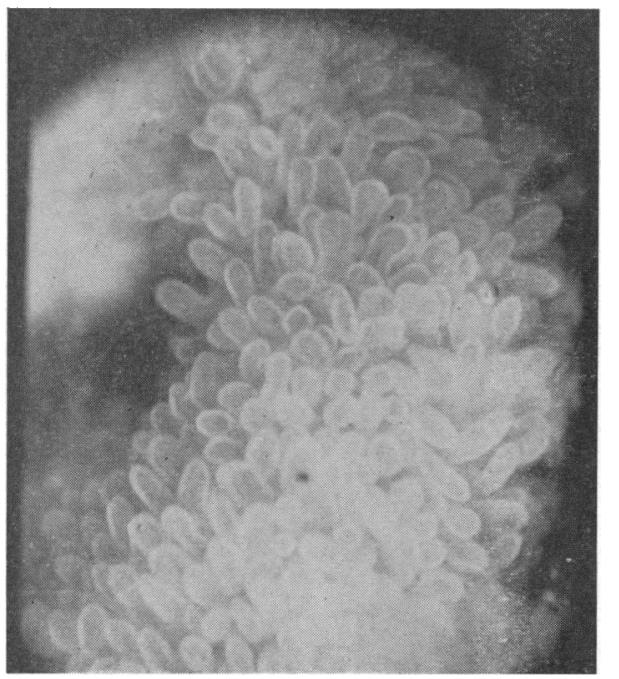

Normal villi.

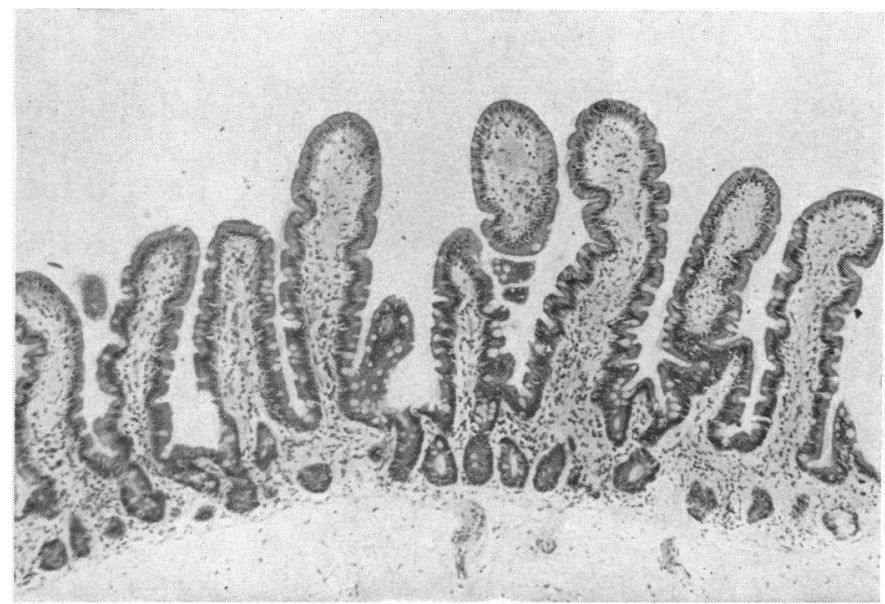

Normal villi.

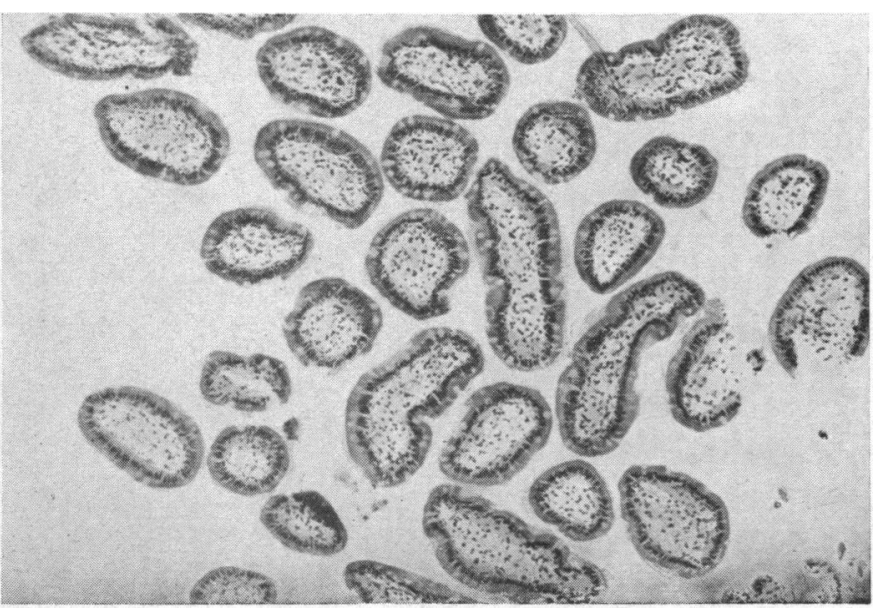

Normal villi.

\section{CATEGORY II}

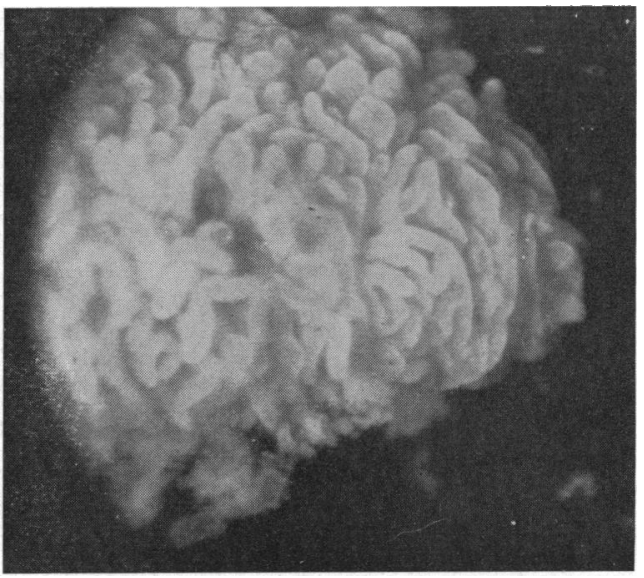

Leaf-shaped villi and villous ridges.

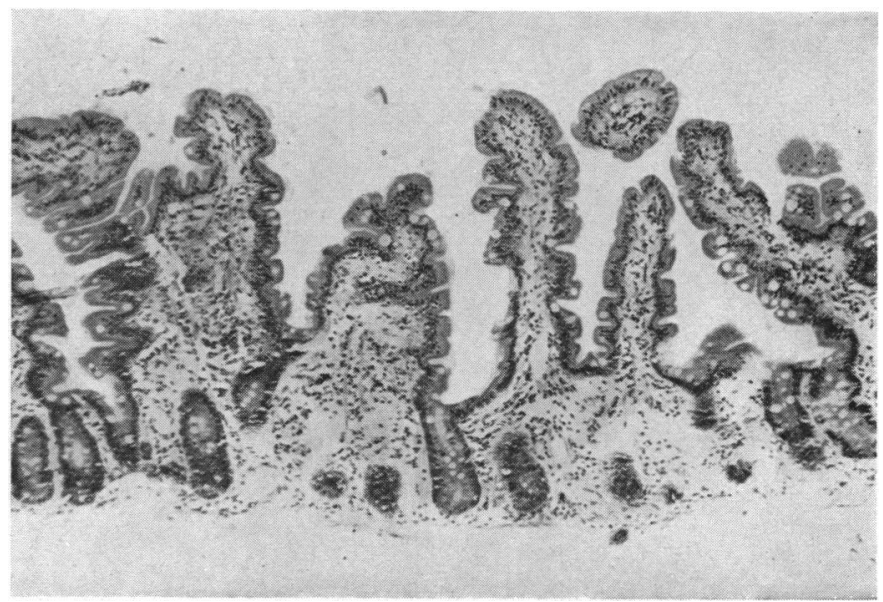

Mild abnormality of villi.

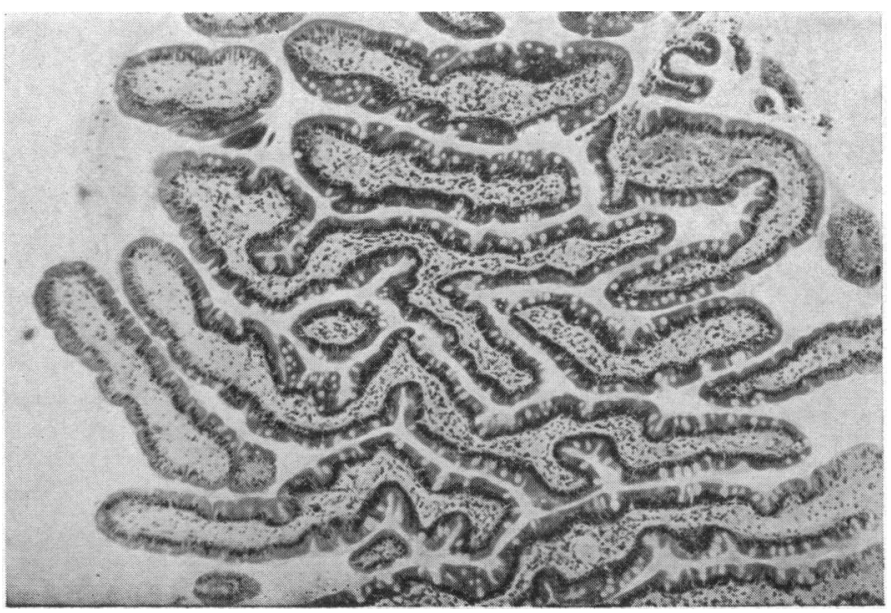

Villous ridging. 
histological appearances in sections cut perpendicularly to the surface of the mucosa $(x 80)$. The bottom row shows the histological appearances in sections cut tangentially to the surface of the mucosa $(\times 80)$.

CATEGORY III

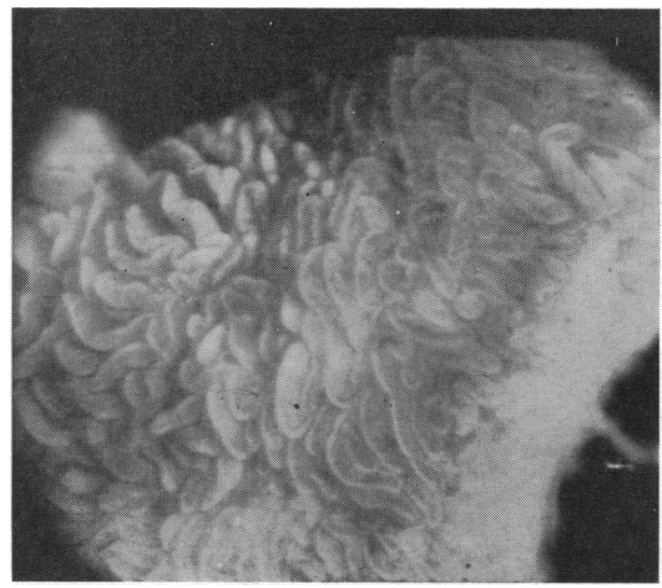

Villous ridges.

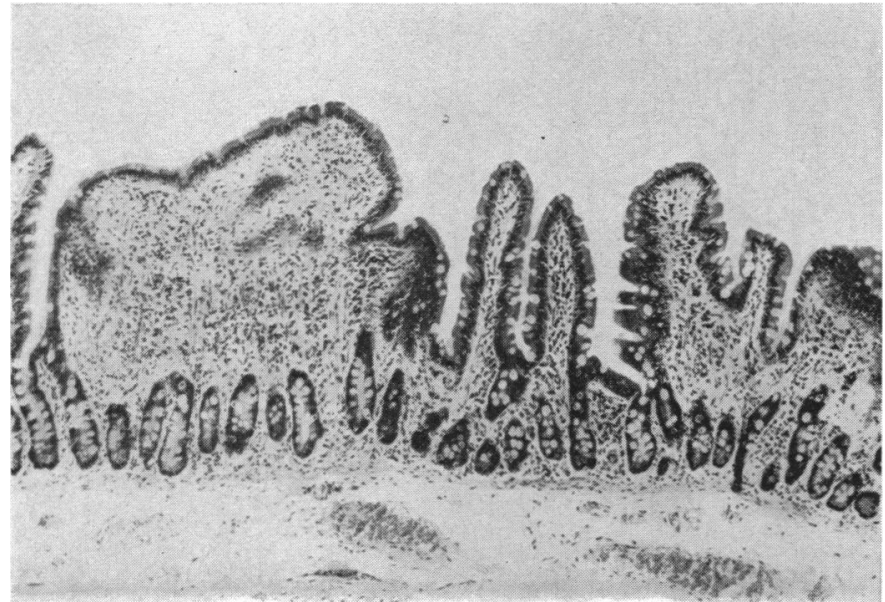

More pronounced abnormality of villi.

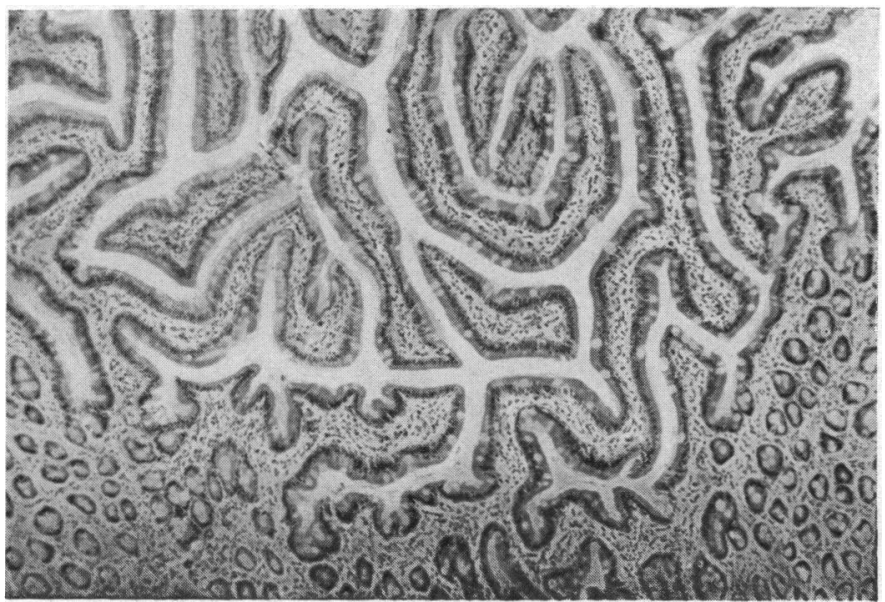

Villous ridging more pronounced.
CATEGORY IV

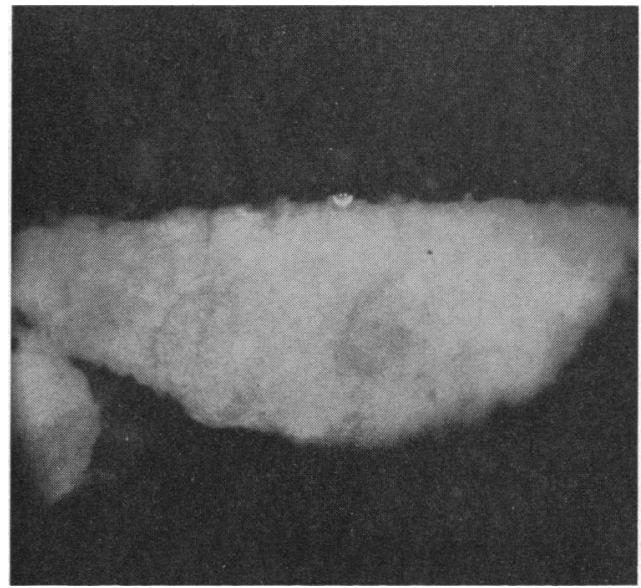

Flat mucosa.

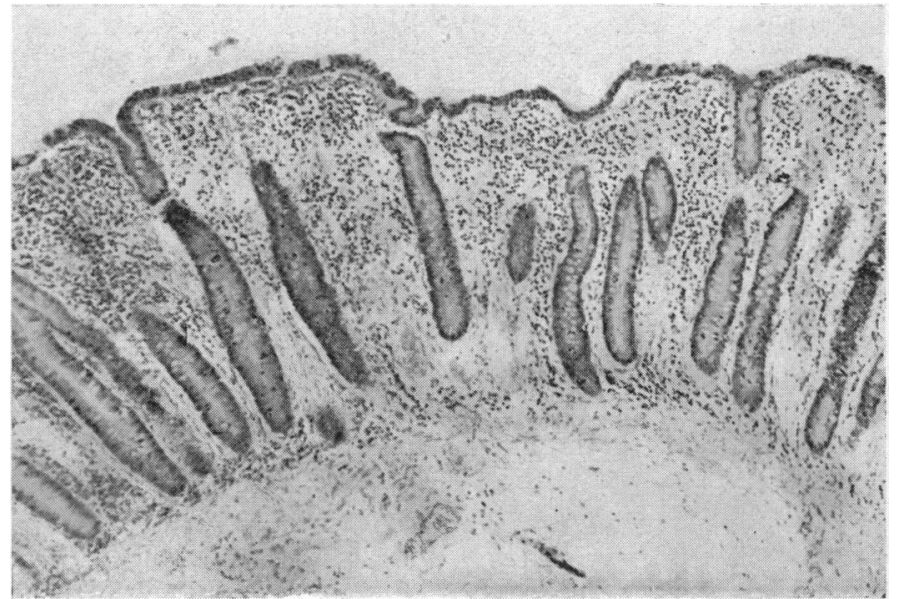

Subtotal villous atrophy.

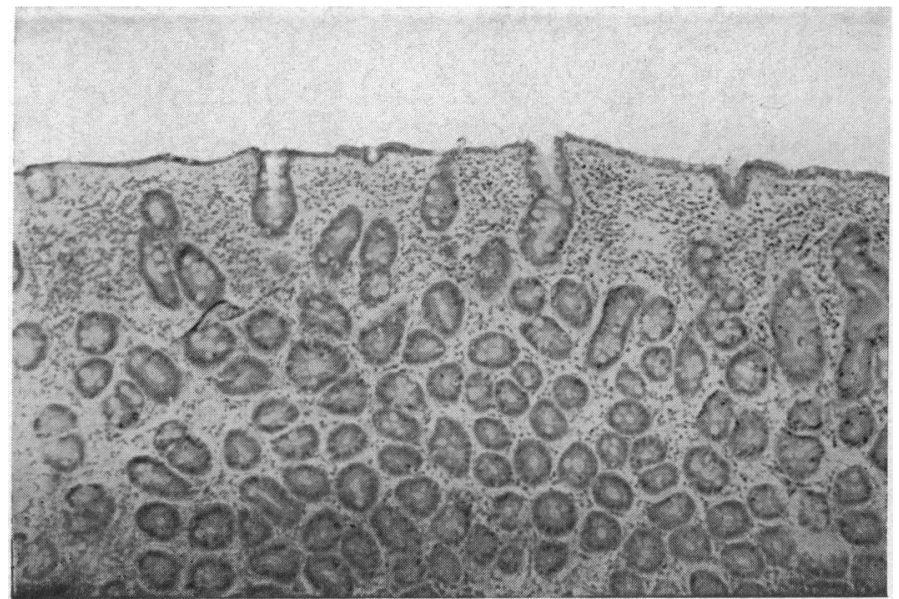

Absence of villi. 
and a flat intestinal mucosa (Case 3). One other patient excreted $40 \%$ of vitamin $\mathrm{B}_{12}$ in the faeces, which is abnormal, and several others had borderline values.

Failure to absorb vitamin $\mathrm{B}_{12}$ is obviously not a prominent feature in ulcerative colitis, and we have not pursued the issuefor example, by giving vitamin $\mathrm{B}_{12}$ in conjunction with intrinsic factor.

\section{Gastric Biopsy Findings}

Gastric biopsy was performed in 18 patients. In the five who were symptom-free the gastric biopsy appearances were normal, but in about half the patients examined during an attack of ulcerative colitis there was evidence of gastritis in the biopsy specimen (Table VIII). In most of these the changes consisted of chronic superficial gastritis, sometimes only focal, and only one showed evidence of early atrophic changes. The close connexion between the clinical state of ulcerative colitis and the finding of gastritis suggests that the gastric changes are transitory and disappear when the patient goes into remission from the ulcerative colitis, but only serial biopsy studies would permit of a definite conclusion.

TABLE VIII.-Relation Between Clinical Activity of Ulcerative Colitis and State of Gastric Mucosa as fudged from Biopsy Specimen

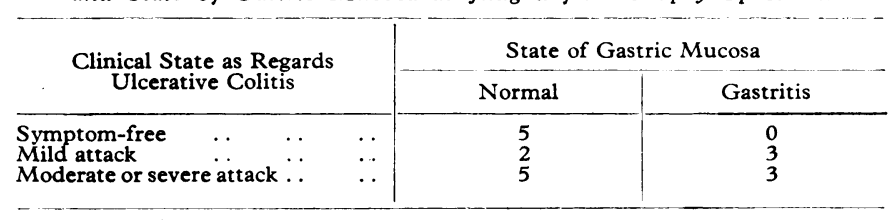

\section{Discussion}

Knowledge of the state of the stomach and small intestine in patients with ulcerative colitis is meagre, and we can find no study with which to compare the present one. Isolated references to the occasional gastric biopsy in ulcerative colitis can be found ; for example, in their monumental study of 1,000 gastric biopsies Wood's group mention the findings in 10 patients with ulcerative colitis, two of whom showed atrophic gastritis (Joske et al., 1955). Peroral small-intestinal biopsy is a more recent investigation than peroral gastric biopsy and was introduced only about seven years ago (Shiner, 1956). This circumstance, coupled with the fact that patients with ulcerative colitis are often too ill to justify any investigations other than those essential for the immediate management of the illness, serves to explain the absence of published studies on the state of the upper small intestine in this disease.

In the event, we have found that the upper small intestine is frequently abnormal in ulcerative colitis. The important factor appears to be the degree of activity of the ulcerative colitis itself. Neither the length of history of the disease nor the age of the patient is an important factor so far as can be judged from the present study.

In view of the fact that in the few patients studied while in perfect remission the small-intestinal biopsy specimens were essentially normal, the prima-facie conclusion must be that small-intestinal abnormalities are transitory and disappear when the colitis becomes inactive. In order to settle this point decisively it would be necessary to make serial biopsy studies on a group of these patients and to equate the state of the upper small intestine with the progress of the ulcerative colitis.

The fact that ulcerative colitis is a severe disease has sharply limited the extent to which we have been able to study smallintestinal function, but in some of the patients we have studied the faecal fat excretion has been found to be abnormally high. These were all patients with symptoms of active ulcerative colitis, and most of them showed abnormal changes in the small- intestinal biopsy specimens. Once again the presumptive conclusion is that the steatorrhoea is a transitory abnormality and that small-intestinal function becomes normal when the patient goes into remission of the ulcerative colitis. Nevertheless, it has an immediate practical significance in that it may help to explain why patients with a severe attack of ulcerative colitis can waste with extreme rapidity ; in effect, not only are there abnormal losses from the inflamed colon but there is also impaired absorption from the small intestine.

From a theoretical point of view it is interesting to speculate on the reasons for the small-intestinal changes in ulcerative colitis. There appear to be at least three distinct possibilities. First, when the colon is affected there may be some reflex or mechanical disturbance in the remainder of the gastro-intestinal system, and this may provoke the abnormal changes in the small-intestinal mucosa. Secondly, there is the possibility that ulcerative colitis is a generalized disease in which the brunt falls on the colon; this view is held by a number of physicians because of the frequency with which organs other than the colon are affected, such as the skin, eyes, joints, mouth, and liver ; if so, the small-intestinal changes can be regarded as one facet of this generalized disease. Thirdly, there is the possibility that the small-intestinal mucosa may become abnormal whenever a person is seriously ill, no matter what the nature of the disease. The small-intestinal epithelium has a very rapid rate of turnover, and it has been estimated by different methods that the entire epithelium is replaced every 24 to 48 hours (Leblond and Stevens, 1948 ; McMinn, 1954 ; Leblond and Messier, 1958 ; Quastler and Sherman, 1959; Bertalanffy and Nagy, 1961; Creamer, 1962). Such a tissue might be unduly susceptible to damage by the metabolic consequences of any severe illness. If so, there is the distinct possibility that structural changes in the villi may follow the disturbance in the epithelium, a view which has been advanced by Creamer (1962) to explain the subtotal villous atrophy which occurs in idiopathic steatorrhoea. From a practical viewpoint, if future studies were to reveal that the small-intestinal mucosa is apt to become abnormal in any serious illness, this in turn might explain why rapid wasting is such a common feature of many severe diseases.

At the moment we are unable to say which of these three possibilities is the most likely, but the whole issue is plainly one which deserves more extensive study.

Gastric biopsy shows that gastritis, usually mild, is often present during an attack of ulcerative colitis although not present in those patients we have examined when symptomfree. This suggests that the gastric mucosa, like the smallintestinal mucosa, is prone to become abnormal when ulcerative colitis is clinically active and presumably reverts to normal when the colitis goes into remission. The absorption of vitamin $\mathbf{B}_{12}$ is usually normal in ulcerative colitis, so that extreme depression of intrinsic-factor secretion cannot occur ; but we have not, as yet, made detailed studies of gastric function.

\section{Summary}

Twenty-five patients with ulcerative colitis have been investigated by peroral small-intestinal biopsy. In addition, the majority of these patients were studied by gastric biopsy, by faecal fat estimation, and by a test of vitamin- $\mathrm{B}_{12}$ absorption.

During an actual attack of ulcerative colitis the smallintestinal mucosa showed varying degrees of abnormality in more than half the patients. When the patients were symptomfree, the small-intestinal mucosa was usually normal.

Likewise, the faecal fat excretion was abnormally high in about half the patients during an actual attack of ulcerative colitis. The patients with high faecal fat excretion usually showed abnormalities in the small-intestinal biopsy specimen.

The absorption of vitamin $B_{12}$ was usually within normal limits, but a few patients showed some degree of impaired absorption. 
Gastric biopsy showed that superficial gastritis was common during an attack of ulcerative colitis, although not seen in any specimens taken from five patients who were symptom-free.

The possible mechanisms and the practical significance of these changes in the small intestine and the stomach during an attack of ulcerative colitis are briefly discussed.

We wish to thank Dr. T. Parry for assistance with the photography.

\section{REFERENCES}

Benson, J. A., Culver, P. J., Ragland, S., Jones, C. M., Drummey, G. D., and Bougas, E. (1957). New Engl. Ұ. Med., 256, 335.

Bertalanffy, F. D., and Nagy, K. P. (1961). Acta anat. (Basel), 45, 362.

Callender, S. T., Turnbull, A., and Wakisaka, G. (1954). Brit. med. $\mathscr{f}$., 1,10

and Evans, J. R. (1955). Clin. Sci., 14, 387.
Cooke, W. T. (1958). Brit. med. 7., $2,261$.

Creamer, B. (1962). Gut, 3, 295.

Crosby, W. H., and Kugler, H. W. (1957). Amer, 7. dig. Dis. 2, 236

Floch, M. H., and Sheehy, T. W. (1962). Gastroenterology, 43, 32.

Fourman, L., P. R. (1948). Clin. Sci., 6, 289.

Holmes, R., Hourihane, D. O'B., and Booth, C. C. (1961a). Lancet, 1, 81 .

Joske - (1961b). Postgrad. med. 7., 37, 717 269.

Leblond, C. P., and Messier, B. (1958). Anat. Rec., 132, 247.

McMinn, R. M. H. (1954). 7. Anat. (Lond.), 88, 527.

Quastler, H., and Sherman, F. G. (1959). Exp. Cell. Res., 17, 420

Santini, R., jun., Sheehy, T. W., and Martinez-de-Jesus, J. (1961) Gastroenterology, 40, 772.

Shiner, M. (1956). Lancet, 1, 85.

Truelove, S. C., and Richards, W. C. D. (1956). Brit. med. F., 1, 1315 .

an and Witts, L. J. (1955). Ibid., 2, 1041.

van der Kamer, J. H., Huinink, H. ten B., and Weyers, H. A. (1949). F. biol. Chem., 177, 347.

\title{
Clinical Trial of 2-Guanidinomethyl $(\mathbf{I}, 4)$ Benzodioxan (Compound I003)
}

\author{
W. S. PEART,* M.D., F.R.C.P. ; M. T. MACMAHON, $\dagger$ M.B., B.S.
}

Brit. med. F., 1964, 1, 398-402

This paper reports the results of a clinical trial of a new hypotensive drug, compound 1003, developed by Pfizer Limited (U.K.) and given the trade name of "envacar."

The structure and pharmacology are described in detail in a paper to be published elsewhere (Reinert). 1003 is the sulphate of 2-guanidinomethyl $(1,4)$ benzodioxan. It has been shown in animals to block the release of adrenaline and noradrenaline from the post-ganglionic sympathetic nerves, and to deplete the tissues of these substances, including the adrenal medulla and the hypothalamus. The pressor effect of noradrenaline infusion into dogs treated with 1003 is markedly reduced owing to the blocking of the $\alpha$-receptor sites. In similarly treated cats, stimulation of the hypothalamus by means of implanted electrodes produces diminished "defence reaction" and a reduction in skin vasoconstriction and muscle vasodilatation compared with the untreated animal.

The two outstanding ways in which this drug differs from guanethidine in animal studies are in its $\alpha$-blocking effect and its depletion of the hypothalamus of noradrenaline. In addition, in rabbits, 1003 depletes the adrenal medulla of noradrenaline and adrenaline whereas guanethidine does not, but in dogs it is depleted by both.

\section{Investigation}

Sixty-two patients have been included in the trial, mostly severe hypertensives ; 50\% had initial diastolic blood-pressures of over $140 \mathrm{~mm}$. ; $48 \%$ between 120 and $140 \mathrm{~mm}$; and $2 \%$ (1 patient) below $120 \mathrm{~mm}$. The age range was from 22 to 72 years, and there were 29 and 33 women.

Thirty-nine patients out of the 62 had had previous treatment with guanethidine, methyldopa, or both ; the results with 1003 in this group are discussed further separately in relation to the results of previous treatment.

* Professor of Medicine, St. Mary's Hospital, London.

† Research Assistant, the Medical Unit, St. Mary's Hospital, London.
Nine patients were in the malignant phase at the time of starting treatment and three had been so before treatment with other drugs. Ten patients had hypertension associated with renal disease and 52 had hypertension for which no cause could be found.

\section{Blood-pressure Readings}

The rate of response to the drug and its duration of action were assessed on patients who started on it while in hospital. The blood-pressure was measured with a sphygmomanometer in the lying and the standing positions and in some cases after exertion. Those followed as out-patients were assessed by casual blood-pressure readings with no deliberate preliminary period of rest.

\section{Mode of Drug Administration}

In-patients were started with a daily dose of $20 \mathrm{mg}$., usually given in one dose in the morning. The dose was doubled every fourth day until an effect was obtained; when partial reduction in blood-pressure occurred the dose was increased more slowly. On several occasions when a more rapid reduction in pressure was required a loading dose of $40 \mathrm{mg}$. was given followed by $20 \mathrm{mg}$. daily for the next two days, then increasing as before.

Out-patients were started on $10 \mathrm{mg}$. daily in a single dose or divided in two. The dose was doubled weekly until an effect was obtained, and again partial reduction in blood-pressure resulted in a more gradual increase in dosage.

If the blood-pressure had not been reduced satisfactorily at $160 \mathrm{mg}$. daily, the dose was halved and polythiazide $1 \mathrm{mg}$. (" nephril," which is polythiazide $1 \mathrm{mg}$. plus $600 \mathrm{mg}$. of potassium chloride incorporated into each tablet) was added once a day. In some cases the dose was increased much beyond this before adding the diuretic, but with little further effect on the blood-pressure. 